\title{
BK virus associated nephropathy after renal transplantation: a single center experience
}

\section{Böbrek transplantasyonu sonrası BK virüs ilişkili nefropati: Tek merkez deneyimi}

\author{
Baris Eser ${ }^{1}$, Ozlem Yayar ${ }^{2}$, Mustafa Sahin 3 , Unsal Savci ${ }^{4}$, Basol Canbakan ${ }^{5}$, Mehmet Deniz Ayli $^{5}$ \\ ${ }^{1}$ Hitit University Faculty of Medicine, Department of Nephrology, Çorum, Turkey \\ ${ }^{2}$ Canakkale State Hospital, Department of Nephrology, Çanakkale, Turkey \\ ${ }^{3}$ Hitit University, Erol Olcok Education and Research Hospital, Department of Medical Biochemistry, Çorum, Turkey \\ ${ }^{4}$ Hitit University, Erol Olçok Education and Research Hospital, Department of Medical Microbiology, Çorum, Turkey \\ ${ }^{5}$ Dışkapı Y1ldırım Beyazıt Education and Research Hospital, Department of Nephrology, Ankara, Turkey
}

Geliş Tarihi: 10.01.2017 Kabul Tarihi: 29.01.2018

Doi: 10.21601/ortadogutipdergisi.376965

\begin{abstract}
Aim: BK virus (BKV) nephropathy is an important cause of allograft failure in renal transplant recipients that is linked to highly potent immunosuppressive therapy. The risk factors associated BKV viremia and BKV associated nephropathy (BKVN) and response to therapy were also evaluated in this study.
\end{abstract}

Material and Method: We retrospectively analyzed 107 renal transplant patients from cadaveric or living related donors between 2008 and 2014. After transplantation, we performed BKV polymerase chain reaction (PCR) assay screening for the presence of viremia in all patients. Peripheral blood samples were collected for screening monthly for first three months, after then every three months until the end of the first transplant year. BKV DNA copies were measured by real time PCR. Allograft biopsies were performed in the presence of clinical indication. All biopsies were analyzed according to Banff criteria and evaluated for the presence of BKVN.

Results: BK virus associated disease was totally detected in 14 patients $(13,1 \%)$ (12 viremia/6 BKVN) of 107 patients. Demographic, clinical and laboratory findings of BKV-related patients (Group I, n: 14) and non-BKV related patients (Group II, n: 93) were compared. Serum creatinine levels were statistically significantly higher in patients with BKV related disease. Additionally, it was detected that older age and tacrolimus usage are important risk factors for developing BKVN $(p<0.05)$. In all cases with BKV associated diseases were managed by reducing immunosuppression and, we used oral $500 \mathrm{mg}$ /day levofloxacin for 1 month for all patients. Additionally in three patients with persistent allograft dysfunction following BKVN, the mycophenolic acid was stopped and oral $40 \mathrm{mg} /$ day leflunomide was subsequently started. Leflunomide therapy continued until the BKV viremia disappeared and graft function was improved in the patients

Conclusion: The use of tacrolimus for BKVN development is associated with a significantly higher risk than cyclosporine. Because BKVN leads to graft loss, renal transplant patients should be screened regularly for BKV replication. Nowadays, reduction of dose immunosuppression is the most common treatment approach. In addition, the use of leflunomide appears to be an additional treatment option.

Keywords: BK virus, Renal transplantation, Nephropathy. 


\section{Öz}

Amaç: BK virüs (BKV) nefropatisi, böbrek transplant alıcılarında allogreft başarısızlığının önemli bir nedeni olup, yüksek derecede potent olan immünsupresif tedaviye bağlıdır. Bu çalışmada BKV viremisi ve BKV ile ilişkili nefropati (BKVN) ile ilişkili risk faktörleri ve tedaviye yanıt da değerlendirildi.

Gereç ve Yöntem: 2008 ve 2014 yılları arasında kadavra kökenli veya canlı ilişkili vericilerden retrospektif olarak 107 renal transplant hastasını analiz ettik. Transplantasyondan sonra, tüm hastalarda vireminin varlığ için BKV polimeraz zincir reaksiyonu (PCR) taraması yaptık. Periferik kan numuneleri ilk üç ayda bir tarama için, daha sonra her üç ayda bir ilk nakil yılının sonuna kadar toplandı. BKV DNA kopyaları gerçek zamanlı PCR ile ölçüldü. Allogreft biyopsileri klinik endikasyona göre yapıldı. Tüm biyopsiler Banff kriterlerine göre analiz edildi ve BKVN varlığı açısından değerlendirildi.

Bulgular: Yüzyedi hastanın 14'ünde (\% 13,1) (12 viremi/6 BKVN) BK virüsü ile ilişkili hastalık tespit edildi. BKV ilişkili hastalığı olan (Group I, n:14) ve olmayan hastalar (Group II, n:93) demografik, klinik ve laboratuvar bulgularına göre karşılaştırıldı. BKV ilişkili hastalığı olanlarda serum kreatinin düzeyleri istatistiksel anlamlı olarak daha yüksek bulundu. Ayrıca, yaşlılık ve takrolimus kullanımının BKVN gelişimi için önemli risk faktörleri olduğu saptandı $(\mathrm{p}<0.05)$. BKV ile ilişkili hastalığı olanlarda immunsüpresif tedavi dozu azaltıldı ve 1 ay boyunca oral 500 mg/gün levofloksasin kullanıldı. Bu hastalardan greft fonksiyon bozukluğu devam eden üç hastada mikofenolik asit tedavisi durduruldu ve oral $40 \mathrm{mg} /$ gün leflunomid tedavisi eklendi. Leflunomid tedavisi BKV viremisi kaybolup greft fonksiyonu düzelene kadar devam edildi.

Sonuç: BKVN gelişiminde takrolimus kullanımı siklosporinden daha yüksek bir risk ile ilişkilidir. BKVN greft kaybına yol açtığından, BKV replikasyonu için böbrek nakli yapılan hastalar düzenli olarak taranmalıdır. Günümüzde immünsüpresyon dozunun azaltılması en sık görülen tedavi yaklaşımıdır. Ek olarak, leflunomid kullanımı ilave bir tedavi seçeneği gibi gözükmektedir.

Anahtar Kelimeler: BK virüsü, renal transplantasyon, nefropati

\section{Introduction}

Polyomavirus hominis 1 is non-enveloped, with a circular double-stranded DNA virus and have three subgroups called BK, JC and SV40 [1]. Humans are the natural host for both, JC virus (JCV) and BK virus (BKV). Although polyomaviruses have high seroprevalence in the humans, they only show clinical signs in immunocompromised patients. BK and JC viral infections in childhood are located as latent infections in the renal and urinary tract epithelium [2]. The human Polyomavirus BK was first isolated in the 1970s [3,4] from the urine of a renal transplant patient with ureteric stenosis, shedding cytopathologically altered cells with atypical nuclear morphology [4]. This patient's initials gave the name to the virus.

After using powerful immunosuppressive agents, acute rejection rate has decreased in renal transplant patients. In addition, long-term patient and graft survival rates have improved after the use of strong triple drug therapy such as calcineurin inhibitors (CNIs), antiproliferative agents and corticosteroids in these patients. The use of these drugs in clinical practice has been associated with a high prevalence of BKV-associated nephropathy (BKVN) [5]. A number of modifiable and non-modifiable risk factor for BKV viremia and BKVN have been reported such as older recipient and donor ( $>65$ years), HLA mismatch, donor BKV seropositive/recipient BKV seronegative, virus associated factors, male recipient gender and immunosuppression [6]. Therefore, we aimed to investigate retrospectively 107 renal transplant patients who were on follow up at our center. The risk factors associated BKV viremia and BKVN and response to therapy were also evaluated in this study.

\section{Materials and Methods}

\section{Patients}

We retrospectively analyzed 107 renal transplant patients from cadaveric or living related donors between 2008 and 2014. The patients' demographic features and follow-up 
data were obtained from their medical records. These patients were evaluated for relevant clinical data including age, gender, primary disease, diabetes mellitus, HLA mismatch, donor type, delayed graft function, acute rejection rates, induction therapy, immunosuppressive drugs, BKV viremia and BKVN.

As immunosuppressive treatment, most of our patients received induction therapy with basiliximab or antithymocyte globulin. The maintenance regimen include prednisolone, an antimetabolite (azathioprine, mycophenolate mophetil (MMF) or mycophenolate sodium (MPA)] and a CNI (tacrolimus or cyclosporine A). All patients received fluconazole, valganciclovir and sulfamethoxazole/trimethoprim as prophylaxis against fungal, viral and pneumocystis jirovecii infection, respectively.

After transplantation, we performed BKV polymerase chain reaction (PCR) assay screening for the presence of viremia in all patients. Peripheral blood samples were collected for screening monthly for first three months, after then every three months until the end of the first transplant year and after when the unexplained rise in serum creatinine at the posttransplant period. BKV DNA copies were measured by real time PCR. BKV viremia was defined as plasma BKV loads above the 104 copies $/ \mathrm{ml}$.

In addition, patients with renal dysfunction were evaluated for the indication renal biopsy. Allograft biopsies were performed in the presence of clinical indication. All biopsies were analyzed according to Banff criteria and evaluated for the presence of BKVN.

\section{Histology}

BKVN was defined by the typical cytopathic changes in the epithelium of glomeruli, tubules and collecting ducts and further confirmed by immunohistochemical nuclear staining for SV40 large T antigen.

\section{Statistical Analysis}

For statistical analysis, data represented mean \pm standart deviation. Differences among the independent groups were analyzed for continuous variables using unpaired $\mathrm{t}$ test to detect possible relationship. For categorical variables, Chi-square test and Fisher exact test used for the comparison of qualitative data between the independent groups. All statistical tests were two tailed, and results were considered significant at $p$ values of $<0.05$.

\section{Results}

A total of 107 renal transplant patients were analyzed from 2008 to 2014. Fortytwo of the kidneys donated by cadaver and sixtyfive by living-related donors. The baseline characterisitics of the 107 patients are presented in Table 1. We performed BKV PCR assay screening for the presence of viremia in all patients. After screening tests, BKV viremia was detected in 14 patients. In addition, six patients were diagnosed with BKVN in renal allograft biopsy specimens. Subsequently, we compared in patients with significant viremia and/or BKVN (Group I, n: 14) and without these findings (Group II, n:93) in terms of demographic characteristcs, clinical findings and biochemical parameters. Serum creatinine level was statistically higher in patients with BKV related disease. Additionally, it was detected that older age and tacrolimus usage are important risk factors for developing BKVN $(p<0.05)$. There was no association with detection of BKV associated disease among recipients characteristics (gender, HLA mismatch, donor source, delayed graft function and acute rejection rates). All findings compared two groups are presented in Table 2.

\begin{tabular}{|c|c|}
\hline Characteristic & Value \\
\hline Age, years & $41.6 \pm 10.7$ \\
\hline Gender, F/M & $43 / 64$ \\
\hline Transplantation vintage, months & $27.9 \pm 30.7$ \\
\hline \multicolumn{2}{|l|}{ Primary renal disease } \\
\hline \multicolumn{2}{|l|}{ Chronic glomerulonephritis } \\
\hline \multicolumn{2}{|l|}{ Diabetes mellitus } \\
\hline \multicolumn{2}{|l|}{ Hypertension } \\
\hline \multicolumn{2}{|l|}{ Obstructive uropathy } \\
\hline \multicolumn{2}{|l|}{ Unknown } \\
\hline Cadaveric/living related donor & $42 / 65$ \\
\hline HLA mismatch number (0-3/4-6) & $61 / 46$ \\
\hline \multicolumn{2}{|l|}{ Induction therapy } \\
\hline ATG & 31 \\
\hline Basiliximab & 65 \\
\hline Without induction & 11 \\
\hline \multicolumn{2}{|l|}{ Maintenance } \\
\hline CNI (Tacrolimus/CsA) & $93 / 8$ \\
\hline mTor inhibitors & 6 \\
\hline Antimetabolite (Aza/MMF or MPA) & $6 / 101$ \\
\hline \multicolumn{2}{|c|}{$\begin{array}{l}\text { F: female; M: male; HLA: human leukocyte antigen; ATG: anti- } \\
\text { thymocyte globulin; CNI: calcineurin inhibitor; CsA: cyclosporine } \\
\text { A; Aza: azathioprine; MMF: mycophenolate mophetil; MPA: } \\
\text { mycophenolate sodium. }\end{array}$} \\
\hline
\end{tabular}


Table 2. Comparison of demographical characteristics and important features between patients with BKV associated and non-BKV associated disease

\begin{tabular}{|l|c|c|c|}
\hline & $\begin{array}{c}\text { Group 1 } \\
(\mathrm{n}=14)\end{array}$ & $\begin{array}{c}\text { Group 2 } \\
(\mathrm{n}=93)\end{array}$ & p value \\
\hline Age, years & $48.1 \pm 11.8$ & $40.9 \pm 10.1$ & $<0.05$ \\
\hline Gender, Female/Male & $4 / 10$ & $39 / 54$ & $\mathrm{NS}$ \\
\hline Diabetes mellitus & $2(14 \%)$ & $16(17 \%)$ & $\mathrm{NS}$ \\
\hline Creatinine, mg/dl & $2.1 \pm 0.4$ & $1.3 \pm 0.6$ & $<0.05$ \\
\hline HLA mismatch 0-3, $\mathrm{n}(\%)$ & $8(57.2)$ & $53(54)$ & $\mathrm{NS}$ \\
\hline HLA mismatch 4-6, $\mathrm{n}(\%)$ & $6(42.8)$ & $40(43)$ & $\mathrm{NS}$ \\
\hline Living-related donor, $\mathrm{n}(\%)$ & $8(57.1)$ & $56(60)$ & $\mathrm{NS}$ \\
\hline Cadaveric, $\mathrm{n}(\%)$ & $6(42.8)$ & $37(40)$ & $\mathrm{NS}$ \\
\hline Anti-thymocyte globulin & $4(28.5 \%)$ & $27(29 \%)$ & $\mathrm{NS}$ \\
\hline Basiliximab & $8(57.1 \%)$ & $53(56 \%)$ & $\mathrm{NS}$ \\
\hline Without induction & $1(7.1 \%)$ & $10(10.8 \%)$ & $\mathrm{NS}$ \\
\hline Delayed graft function, $\mathrm{n}(\%)$ & $3(21.4)$ & $27(29)$ & $\mathrm{NS}$ \\
\hline Acute rejection, $\mathrm{n}(\%)$ & $4(28.5)$ & $13(14)$ & $\mathrm{NS}$ \\
\hline Tacrolimus usage, $\mathrm{n}(\%)$ & $14(100)$ & $79(84.9)$ & $<0.05$ \\
\hline NS; Non significance & & & \\
\hline
\end{tabular}

In all cases with BKV associated diseases were managed by reducing immunosuppression. Antiproliferative agent was initially reduced by $25-50 \%$ after detection of viremia followed by subsequent serum tacrolimus level reduction to a 4-6 $\mathrm{ng} / \mathrm{ml}$ range, if necessary to achieve viral clearence. Besides this, we used oral $500 \mathrm{mg}$ /day levofloxacin for 1 month for all patients. Additionally in three patients with persistent allograft dysfunction following BKVN, the mycophenolic acid was stopped and oral $40 \mathrm{mg}$ /day leflunomide was subsequently started. Leflunomide therapy continued until the BKV viremia disappeared and graft function was improved in patients treated with leflunomide. None of our patients had graft loss due to BKVN.

\section{Discussion}

Renal transplantation does lead to a significant improvement in the patient's quality of life as well as provide a longer survival than other renal replacement therapies. Mortality risk in renal transplantation is less than half of that for dialysis patients [7]. The incidence of acute rejection in the early postttransplant period is significantly reduced with the use of newer immunosuppressive agents such as CNIs, antiproliferative agents steroids, that are often supplemented by induction with basiliximab or antithymocyte globulins. In addition, long term graft survival was achieved marked improvements with advances in immunosuppressive therapy [8]. Despite these advances, powerful immunosuppressive protocols have also lead to the emergence of infectious complications such as BKV associated disease in early posttransplantation period. BKV infection has been described as causing several different manifestations such as ureteral stenosis, hemorrhagic cystitis, BKVN [9]. Of these, BKVN is most important manifestation because of its association with graft loss [10]. A number of demographic and clinical factors have been associated with increased the risk of BKV infection as mentioned earlier. In our study, tacrolimus usage and advanced recipient age were found to be significantly higher in patients with BKV viremia and/or BKVN compared to in patients without these findings. Brennan et al. reported that the highest levels of BKV viruria were apparent following the combination of tacrolimus-MPA and lowest with cyclosporine-MPA but failed to demonstrate a difference in the rates of BK viraemia [11]. In another multicenter study, 682 renal transplant receivers received basiliximab as an induction agent, MPA and steroids were randomized to either tacrolimus and cyclosporine. BK viremia was found statistically significant higher in recipients that received tacrolimus compared to cyclosporine at six and twelve months [12]. This finding has been confirmed in US Registry [13].

The risk of $\mathrm{BKV}$ infection can be related to overimmunosuppression. In a study including 240 renal transplant receivers shows association between BKV infection and drug levels. Both high serum tacrolimus levels (>10 ng/ml) and MPA (AUC 0-12 hr $>50 \mathrm{hr} \mathrm{mg/L)}$ were detected as risk factors for BKV infection [14]. In another study, 56 renal transplant receivers with BKV viremia compared with $71 \mathrm{BKV}$ negative recipients. The results of this study demonstrated that MMF and tacrolimus could promote BKV viremia [15]. In our study, we didn't find statistically significant difference between serum tacrolimus level and BKV viremia. Excessive immunosuppression is determined not only by immunosuppressive drugs but also by the humoral and cellular immunity of the recipient. In a prospective singlecenter randomized controlled trial of 105 renal transplant patients, Renner and collaguaes demonstrate that the incidence of BKV viremia to be increased among patients with defective cytotoxic CD8(+) T-cell-dependent immune reactivity. Recipients who progressed from BKV viremia to overt BKVN showed an additional immunologic defect in CD4(+) T-cell function. Patients on a tacrolimus plus MMF-based immunosuppression were at higher risk to develop BKV viremia [16].

In another data of our study demonstrates that the patients with $\mathrm{BKV}$ viremia and $\mathrm{BKVN}$ is more frequent in older age 
than those without these findings. In addition to powerful immunosuppressive therapy, Hirsch et al. reported that male gender and older recipient age were identified as independent risk factors for BKV viremia at month 12 in their study including 682 renal transplant patients [12]. Both patient determinants have been reported previously as being associated with BKVN in some single-center studies [17]. In our study, despite the fact that older age was found statistically significant different consistent with the literature, gender was not found to be different between the two groups. This can be explained by the small number of patients included in the study.

There is limited knowledge on BKV specific immunity. In a study evaluating BKV specific cellular and humoral immunity among 122 immunocompetent individuals (1-84 years), it has been shown to be highly prevalent in young individuals. BKV specific cellular and humoral immunity reaches its maximum dose aged between 20 and 30 years and after progressively decrease to below detection limit [18]. These results may explain why BKV associated diseases in older renal transplant recipients appear more frequently than young ones.

The presence of biopsy proven acute rejection existence was found higher for BKV viremia and BKVN in some studies $[14,19,20]$. High-risk patients treated with more intensive immunosuppression may be an important factor in the increasing incidence of BKV associated diseases. In our study, acute rejection episodes were documented by biopsy in $28.5 \%(n=4)$ of in patients with BKV associated diseases compared with $14 \%(n=14)$ of in patients without these diseases. The difference did not reached statistically significant, probably because of the small number of patients. Quinolone antibiotics such as levofloxacin may be effective in the treatment of BKV infections. In a retrospective study including 160 renal transplant recipients not receiving fluoroquinolone for prophylaxis and 40 received a fluoroquinolone for treatment of a bacterial infection. Gabardi et al. suggested that 1-month fluoroquinolone course after transplantation was associated with significantly lower rates of BKV viremia at 1 year compared with those with no fluoroquinolone [21]. However, controversial results have been reported in recent studies on this issue $[22,23]$. A recently published meta-analysis suggests that fluoroquinolones may be ineffective in the prevention of BK polyomavirus infection in renal transplant patients [24].
In our research, we used $500 \mathrm{mg}$ levofloxacin daily for 1 month in all BKV associated disease diagnosed renal transplant receivers. Besides this, antiproliferative agent was reduced by $25-50 \%$ after detection of viremia followed by subsequent serum tacrolimus level reduction to a 4-6 $\mathrm{ng} / \mathrm{ml}$ range, if necessary to achieve viral clearence. The immunomodulatory drug leflunomide has antiviral activity against $\mathrm{BKV}$ in addition to immunosuppressive action [25]. In a study including 12 renal transplant patients with biopsy proven BKVN were treated with reduced immunosuppression and leflunomide. After treatment, clearance of BKV from blood was achieved in five of these twelve patients [26]. In our three patients who diagnosed BKVN with persistent graft dysfunction, MMF was stopped and leflunomide treatment was subsequently started. After treatment, graft function was improved in all patients treated with leflunomide.

Our study have a number of limitations. The main limitations are retrospective design and relatively small number of patients included. Another limitation of the study is the lack of detection of BKV in urine samples. Despite these limitations our results demonstrate that excessive immunosuppression and older age are important risk factors. In conclusion, tacrolimus is associated significantly higher risk than cyclosporine regarding BKV associated diseases in renal transplant patients treated with MMF and steroids. Older age is an another risk factor due to our study. Because BKVN leads to graft loss, renal transplant patients should be screened regularly for BKV replication. Nowadays, reduction of maintanence immunosuppression is the most common treatment approach. In addition, it is important to follow viremia with PCR assay monthly for renal transplant receivers with BKV viremia. Use of leflunomide appears an adjunctive treatment option in renal transplant recipients receiving the diagnosis of $\mathrm{BKVN}$.

\section{Declaration of conflicting interests}

The author declared no conflicts of interest with respect to the authorship and/or publication of this article.

\section{References}

1. Tan CS, Koralnik IJ. JC, BK, and other polyomaviruses: progressive multifocal leukoencephalopathy. In: Mandell GL, editor. Principles and practices of infectious diseases. 10th ed. Philadelphia: Churchill Livingstone; 2009.

2. Knowles WA, Pipkin P, Andrews N, et al. Population-based study of antibody to the human polyomaviruses BKV and JCV and the simian polyomavirus SV40. J Med Virol 2003; 71:115-23 
3. Hirsch HH, Steiger J. Polyomavirus BK. Lancet Infect Dis 2003; 3: $611-23$.

4. Gardner SD, Field AM, Coleman DV, Hulme B. New human papovavirus (B.K.) isolated from urine after renal transplantation. Lancet 1971; 1: 1253-57.

5. Mengel M, Marwedel M, Radhermacher J, etal. Incidence of polyomavirus nephropathy in renal allografts: influence of modern immunosupressive drugs. Nephrol Dial Transplant 2003;18:1190-6.

6. Acott P, Babel N. BK virus replication following kidney transplant: Does the choice of immunosupressive regimen influence outcomes? Ann Transplant 2012;17:86-99.

7. Wolfe RA, Ashby VB, Milford EL, et al. Comparison of mortality in all patients on dialysis, patients on dialysis awaiting transplantation, and recipients of a first cadaveric transplant. $\mathrm{N}$ Engl J Med, 1999;341:1725-30.

8. Kalluri HV, Hardinger KL. Current state of renal transplant immunosuppression: Present and future. World J Transplant 2012; 2:51-68

9. Hirsch HH, Steiger J. Polyomavirus BK. Lancet Infect Dis 2003; 3: 611-23.

10. Hirsch HH, Brennan DC, Drachenberg CB, et al. Polyomavirusassociated nephropathy in renal transplantation: Interdisciplinary analyses and recommendations. Transplantation 2005;79: $1277-$ 86.

11. Brennan DC, Agha I, Bohl DL, et al. Incidence of BK with tacrolimus versus cyclosporine and impact of preemptive immunosuppression reduction. Am J Transplant 2005;5:582-94.

12. Hirsch HH, Vincenti F, Friman $\mathrm{S}$, et al. Polyomavirus BK replication in de novo kidney transplant patients receiving tacrolimus or cyclosporine: a prospective, randomized, multicenter study. Am J Transplant 2013;13: 136-45.

13. Dharnidharka VR, Cherikh WS, Abbott KC. An OPTN analysis of national registry data on treatment of BK virus allograft nephropathy in the United States. Transplantation 2009;15:87:1019-26.

14. Borni-Duval C, Caillard S, Olagne J, et al. Risk factors for $\mathrm{BK}$ virus infection in the era of therapeutic drug monitoring. Transplantation 2013 27;95:1498-505.

15. Steubl D, Baumann M, Schuster T, et al. Risk factors and interventional strategies for BK polyomavirus infection after renal transplantation Scand J Urol Nephrol 2012;46:466-74.

16. Renner FC, Dietrich H, Bulut N, Celik D, Freitag E, Gaertner N, et al. The risk of polyomavirus-associated graft nephropathy is increased by a combined suppression of CD 8 and CD4 cell-dependent immune effects. Transplant Proc $2013 ; 45: 1608-10$.
17. Ramos E, Drachenberg CB, Papadimitriou JC, et al. Clinical course of polyoma virus nephropathy in 67 renal transplant patients. J Am Soc Nephrol 2002;13:2145-51.

18. Schmidt T, Adam C, Hirsch $\mathrm{HH}$, et al. BK polyomavirus-specific cellular immune responses are age-dependent and strongly correlate with phases of virus replication. Am J Transplant 2014;14:1334-45.

19. Hirsch HH, Knowles W, Dickenmann M, et al. Prospective study of Polyomavirus Type BK Replication and nephropathy in renaltransplant recipients. N Engl J Med 2002; 347:488-96.

20. Schold JD, Rehman S, Kayle LK, Magliocca J, Srinivas TR, Meier $\square$ Kriesche HU. Treatment for BK virus: incidence, risk factors and outcomes for kidney transplant recipients in the United States. Transpl Int 2009; 22:626-34.

21. Gabardi S, Waikar SS, Martin S, et al. Evaluation of fluoroquinolones for the prevention of BK viremia after renal transplantation. Clin J Am Soc Nephrol 2010;5: 1298-304.

22. Min D, Vu D, Kawewat B, et al. Effect of ciprofloxacin prophylaxis on BK virus infection after renal transplantation. Am J Transplant 2013;13: 434 [Abstract].

23. Eng M, Jones $\mathrm{C}$, Marvin $\mathrm{M}$. Fluoroquinolone prophylaxis is ineffective in preventing $\mathrm{BK}$ polyoma viremia after renal transplant. Transplantation 2014; 98: 86 [Abstract].

24. $21 \mathrm{C}$ - Song TR, Rao ZS, Qiu Y, et al. Fluoroquinolone prophylaxis in preventing BK polyomavirus infection after renal transplant: A systematic review and meta-analysis. Kaohsiung J Med Sci 2016 Mar;32: 152-9.

25. Bernhoff E, Tylden GD, Kjerpeseth LJ, Gutteberg TJ, Hirsch HH, Rinaldo $\mathrm{CH}$. Leflunomide inhibition of $\mathrm{BK}$ virus replication in renal tubular epithelial cells. J Virol 2010;84:2150-6.

26. Faguer S, Hirsch HH, Kamar N, et al. Leflunomide treatment for polyomavirus BK- associated nephropathy after kidney transplantation. Transpl Int 2007;20):962-9.

Corresponding Author: Mustafa Şahin, Hitit University, Erol Olçok Education and Research Hospital, Department of Medical Biochemistry, 19020, Çorum, Turkey

Email: mustafaistanbulx@hotmail.com 